\title{
REKONTRUKSI AYAT-AYAT AKUNTANSI SYARIAH
}

\author{
Nurhadi \\ Sekolah Tinggi Agama Islam (STAI) Al-Azhar Pekanbaru \\ Email: alhadicentre@yahoo.co.id
}

\begin{abstract}
This paper also tries to describe the values of wisdom and values of the Qur'an in natural accounting practices in sharia. One of the aspirations of the disclosure of these values was stated in the excavation of science in universities as HR regeneration in the field of sharia accounting. If the basis of revelation is of course the truth is in accordance with justice and buman benefit. Therefore it is considered very necessary to reveal the basics of al-Qur'an revelation in confirming Islamic accounting knowledge, so that it is formed in full by reconstructing economic accounting verses. So the result is that the syariah accounting verses with the parent paragraph (Q.S (2): 282; (26): 181-184; (49): 6; (17): 35). Whereas there are 9 types of sharia accounting reporting principles, namely: Reported correctly (Q.S (10): 5); Quickly report (Q.S (2): 202; (3): 19; (5): 4; (13): 41); Created by experts (accountants) (Q.S (13): 21; (13): 40; (23): 117; (88): 26); Bright, clear, firm and informative (Q.S (17): 12; (14): 41; (84): 3); Contains comprehensive information (Q.S 6: 52; 39:10); Information is addressed to all parties involved horizontally and vertically (QS (2): 212; (3): 27; (3): 37; (13): 18; (13): 40; (24): 38; (38): 39; (69): 52); Detailed and thorough (Q.S (65): 8); No manipulation (Q.S (69): 20; (78): 27); Performed continuously (not negligent) (Q.S (21): 1).
\end{abstract}

Keywords: Reconstruction, Verses, Accounting, Sharia

\begin{abstract}
Abstrak : Tulisan ini juga mencoba medeskriptifkankan nilai-nilai kearifan dan nilai-nilai alQur'an dalam praktik akuntansi yang alamiah secara syariah. Salah satu manispestasi dari pengungkapan nilai-nilai tersebut tertuang dalam penggalian ilmu di perguruan tinggi sebagi kaderisasi SDM di bidang akuntansi syariah. Jika dasarnya dari wahyu tentu kebenaranya sesuai dengan keadilan dan kemaslahatan manusia. Oleh karenanya dianggap sangat perlu untuk mengungkapkan dasar-dasar wahyu al-Qur'an dalam mengkonpirmasi keilmuan akuntansi syariah, sehingga terbentuk secara utuh dengan merekontruksi ayat-ayat akuntansi ekonomi. Maka hasilnya bahwa ayat-ayat akuntansi syariah dengan induk ayatnya (Q.S (2): 282; (26): 181-184; (49): 6; (17): 35). Sedangkan prinsip pelaporan akuntansi syariah ada 9 macam, yaitu: Dilaporkan secara benar (Q.S (10): 5); Cepat laporannya (Q.S (2): 202; (3): 19; (5): 4; (13): 41); Dibuat oleh ahlinya (akuntan) (Q.S (13): 21; (13): 40; (23): 117; (88): 26); Terang, jelas, tegas dan informatif (Q.S (17): 12; (14): 41; (84): 3); Memuat informasi yang menyeluruh (Q.S 6: 52; 39:10); Informasi ditujukan kepada semua pihak yang terlibat secara horizontal maupun vertikal (Q.S (2): 212; (3): 27; (3): 37; (13): 18; (13): 40; (24): 38; (38): 39; (69): 52); Terperinci dan teliti (Q.S (65): 8); Tidak teradi manipulasi (Q.S (69): 20; (78): 27); Dilakukan secara kontinu (tidak lalai) (Q.S (21): 1).
\end{abstract}

Kata Kunci: Rekontruksi, Ayat-Ayat, Akuntansi, Syariah

Islamika : Jurnal Keislaman dan Ilmu Pendidikan

Volume 2, Nomor 2, Juli 2020; 227-250

https:// ejournal.stitpn.ac.id/index.php/islamika 


\section{PENDAHULUAN}

Kaburnya pemahaman sebahagian umat Islam tentang ilmu akuntansi, lalu memunculkan pertanyaan, apakah ilmu akuntansi bahagian dari ajaran Islam?. Persoalan ini begitu menarik, kerana agama seperti yang difahami oleh banyak kalangan, hanyalah sekumpulan norma yang lebih menekankan pada isu moral. Oleh itu, prinsip-prinsip kehidupan praktikal yang mengatur urutan hidup moden dalam urus niaga yang diatur dalam perakaunan, tidak termasuk dalam ruang lingkup agama. ${ }^{1}$ Anggapan perakaunan Islam (perakaunan berdasarkan syariah Islam) adalah wajar untuk dipersoalkan oleh orang. Begitu juga, pada masa lalu orang meragui dan mempersoalkan bagaimana ekonomi Islam. Sekiranya kita mengkaji dengan lebih mendalam dan mendalam sumber ajaran Islam adalah al-Quran, kita akan menemui ayat-ayat dan hadis yang membuktikan bahawa Islam juga membincangkan ilmu perakaunan. Sebagaimana di dalam al-Qur'an akuntansi dimulai dari (QS 2:282) yang artinya : "orang-orang beriman, apabila kamu melakukan transaksi utang piutang untuk jangka waktu yang telah ditentukan, maka tuliskanlah". ${ }^{2}$

Pada dasarnya akuntansi telah berkembang secara dinamis sesuai zamanya, mulai dari yang paling sederhana, yang memandang akuntansi sebagai sistem pencatatan, sampai dengan yang paling mutakhir yang memandang akuntansi sebagai sistem informasi yang sarat dengan penggunaan teknologi. Perkembangan akuntansi tersebut dipengaruhi oleh beberapa faktor diantaranya adalah kondisi budaya, ekonomi, hukum, sosial, dan politik dimana akuntansi itu berkembang. Menurut Suwarjono, untuk dapat mengembangkan struktur dan amalan perakaunan di wilayah atau negara tertentu tidak cukup hanya dengan mempelajari amalan perakaunan yang berjalan sendiri. ${ }^{3} \quad$ Di balik praktik akuntansi sebenarnya terdapat seperangkat gagasan-gagasan yang melandasi praktik tersebut berupa asumsi-asumsi dasar, konsep-konsep, penjelasan, deskripsi dan penalaran. ${ }^{4}$

\footnotetext{
${ }^{1}$ Milam Ashuri. Akuntansi Syariah, lihat wibesite online di alamat https://milamashuri.wordpress.com/2015/04/05/akuntansi-syariah/.diakses.tgl.12.september.2018. ${ }^{2}$ Departemen Agama RI. 2015. Al-Qur'an dan Terjemahanya. Jakarta. Depag RI), hlm. 70

3 Suwarjono. 2005. Teori Akuntansi Perekayasaaan Pelaporan Kenangan. Yogyakarta. BPFE, hlm. 1 ${ }^{4}$ M. Anas. 2018. Pembelajaran Akuntansi Berbasis Spiritualitas, Budaya Dan Kearifan Lokal (Jurnal Akuntansi \& Ekonomi FE. UN PGRI Kediri Vol. 3 No. 1, Maret), hlm. 35
} 
Kesadaran umat Islam akan konsep ekonomi Islam menjadi bukti boomingnya ekonomi Islam ranah akademis dunia Pendidikan, dimulai dari setingkat sarjana muda (D-3), S-1, S-2 dan S-3 dalam perguruan tinggi Islam, baik swasta maupun Negeri, membuat para pakar ekonomi Islam berbenah dalam melengkapi struktur ekonomi Islam sebagai ilmu yang sangat komprehenship. Oleh karena itu salah satu cabang ilmu ekonomi Islam adalah Akuntansi Syariah. Maknanya akuntansi yang sejalan dengan nilai-nilai wahyu al-Qur'an dan tuntunan sunnah Rasul saw. ${ }^{5}$

Urgensi ilmu akuntansi menjadi boom bastick dunia internasional. Ini telah menyebabkan globalisasi dalam perakaunan kerana dunia perniagaan dan ekonomi yang semakin meningkat. Tidak dapat dinafikan bahawa apabila semua dimensi dunia perniagaan dan ekonomi menjadi global, perakaunan juga memasuki dimensi antarabangsa global. Menunjukkan bahawa perakaunan adalah sebahagian daripada dunia perniagaan dan ekonomi. Konsep baru dalam ilmu akuntansi yang muncul akibat globalisasi dan perkembangan dunia bisnis yang semakin cepat adalah munculnya konsep akuntansi sosial dan lingkungan, baik dipengaruhi oleh kultur budaya kerja atau ideology keyakinan sosial masyarakat. Akuntansi sosial dan lingkungan merupakan perubahan paradigma dari akuntansi kovensional kepada akuntansi social lingkungan setempat. Akuntansi sosial dan lingkungan memasukkan dimensi sosial dan lingkungan ke dalam pencatatan akuntansi. Hasil akhirnya adalah akuntansi sosial dan lingkungan berpusat tidak hanya pada indikator ekonomi yang dicapai suatu entitas, tetapi juga memikirkan dampak sosial dan lingkungan yang ditimbulkan dari kegiatan entitas. Salah satu entitas tersebut yang sesuai dengan perobahan dimensi social dan lingkungan umat Islam adalah teori akuntansi syariah. ${ }^{6}$

Tulisan ini mencoba untuk mensintesiskan unsur-unsur spiritualitas, budaya, dan kearifan

lokal, khususnya umat Islam. Tulisan ini juga mencoba medeskriptifkankan nilai-nilai kearifan dan nilai-nilai al-Qur'an dalam praktik akuntansi yang alamiah secara syariah. Dengan memasukkan unsur-unsur spiritual, buadaya, dan kearifan local umat. ${ }^{7}$ Salah

${ }^{5}$ Ali Mauludi AC. 2014. Akuntansi Syariab; Pendekatan Normatif, Historis dan Aplikatif. Iqtishadia Vol . 1 No. 1 Juni, hlm. 59

6M. Anas. 2018. Pembelajaran Akuntansi Berbasis Spiritualitas, Budaya Dan Kearifan Lokal, hlm. 35 ${ }^{7}$ Ibid., hlm. 36 
satu manispestasi dari pengungkapan nilai-nilai tersebut tertuang dalam penggalian ilmu di perguruan tinggi sebagi kaderisasi SDM yang berkualitas di bidang akuntansi syariah tersebut. Penguasaan terhadap ilmu pengetahuan dan teknologi tidak cukup, perguruan tinggi juga dituntut mampu membentuk lulusan yang memiliki karakter, yaitu insan yang memiliki jiwa yang jujur, cerdas, tangguh dan berprestasi dalam landasan Iman dan Tagwa. Hal ini penting mengingat, perguruan tinggi merupakan akhir dari proses pendidikan formal, setelah pendidikan dasar dan pendidikan menengah. ${ }^{8}$

Munculnya kajian tersebut dalam perguruan tinggi mengantarkan akan perkembangan pola piker manusia sesuai dengan zamannya, yang biasanya selalu diiringi dengan perubahan perilaku manusia. Perakaunan tingkah laku adalah sebahagian daripada disiplin perakaunan yang mengkaji hubungan antara tingkah laku manusia dan sistem perakaunan, serta dimensi tingkah laku organisasi di mana manusia dan sistem perakaunan berada dan keberadaannya diakui. ${ }^{9}$ Keprilakuan akuntan sesuai dengan prinsif dasar keilmuan tersebut. Jika dasarnya dari wahyu tentu kebenaranya sesuai dengan keadilam dan kemaslahatan manusia. Oleh karenanya dianggap sangat perlu untuk mengungkapkan dasar-dasar wahyu dalam mengkonpirmasi keilmuan tersebut, agar sesuai dengan fitrahnya manusia selalu ingin mendapatkan keseimbangan dan keadilan dalam bersosial dan berekonomi secara bersama.

\section{KAJIAN PUSTAKA}

\section{Sejarah Akuntansi Syariah}

Sejarah mencatat bahwa akuntansi merupakan salah satu bentuk profesi tertua. Dari sejak jaman prasejarah, setiap keluarga memiliki perhitungan tersendiri

${ }^{8}$ Marhaendra Kusuma. 2017. Internalisasi Nilai Pancasila Dalam Mata Kuliah Akuntansi Biaya (Suatu Studi Pengukuran Efektivitas Learning Outcome). Jurnal Akuntansi \& Ekonomi FE. UN PGRI Kediri Vol. 2 No. 2, September.

2017, hlm. 71

'I Wayan Suartana. 2010). Akuntansi Keperilakuan; Teori dan Implementasi. Yogyakarta: Penerbit Andi; Elex Sarmigi. 2018. Analisis Komparasi Perilaku Etis Mahasiswa Akuntansi Stie Sakti Alam Kerinci Dengan STIE Sumatera Barat Dan Faktor-Faktor Yang Mempengarubinya (Jurnal Akuntansi \& Ekonomi FE. UN PGRI Kediri Vol. 3 No. 1, Maret, hlm. 44 
untuk mencatat makanan dan pakaian yang harus mereka persiapkan dan mereka gunakan pada saat musim dingin. ${ }^{10}$ Ketika orang mula mengenali kewujudan "perdagangan", pada masa yang sama mereka biasa dengan konsep nilai dan mula mengenali sistem monetari. Bukti pembukuan dapat dijumpai dari awal kerajaan Babilonia (4500 SM), Firaun Mesir dan kod Hammurabi (2250 SM), seperti yang terdapat dalam catatan perakaunan di Ebla, Syria Utara. ${ }^{11}$

Secara historis pembahasan tentang latar belakang lahirnya akuntansi syari'ah tidak lepas dari tinjauan kondisi akuntansi yang ada di tanah jazirah Arab sebelum Islam. Dalam literatur sejarah peradaban bangsa Arab, perhatian bangsa Arab sangat besar terhadap perdagangan. ${ }^{12}$ Oleh kerana itu, mereka telah menggunakan asas penggunaan perakaunan yang bertujuan untuk mengira urus niaga mereka dan mengetahui perubahan dalam jumlah aset. Jadi konsep perakaunan pada masa itu dapat dilihat dalam pembukuan berdasarkan kaedah penambahan statistik sesuai dengan peraturan penambahan. Untuk melakukan pembukuan ini, ada yang dilakukan oleh peniaga sendiri dan ada yang menggaji akauntan khusus. Pada masa itu, seorang akauntan dipanggil katibul amwal (pendaftar kewangan). ${ }^{13}$ Namun pada waktu itu masih ada pembukuan sistem riba yang dalam islam dikenal dengan riba jahiliyah. Kemudian islam dating yang dibawa oleh Nabi Muhammad saw membenahi konsep akuntansi yang bersifat jahiliyah tersebut dengan konsep akuntatsi syari'ah yang memberikan kemashlahatan bagi umat manusia. ${ }^{14}$ Kemudian pada perkembangan selanjutnya akuntansi syari'ah menglami penyesuaian dengan kondisi setempat. Perbandingan panjang perakaunan yang diketahui di Negara Islam dengan perakaunan yang diketahui oleh kebanyakan orang adalah 800 tahun sebelumnya, kerana perakaunan Islam telah diketahui sejak keturunan al-Qu'an, iaitu

\footnotetext{
${ }^{10}$ Wartoyo S. 2013. Akuntansi Syariah : Sebuah Tinjauan Historis, Jurnal Adzkia Islamic and Finance Volume 1 No 1 t.th, hlm. 38-39

${ }^{11}$ Sri Nurhayati \& Wasilah. 2011. Akuntansi Syari'ah di Indonesia. Jakarta: Salemba Empat, hlm. 51; Sri Nurhayati. 2013. Akuntansi Syariah di Indonesia. Salemba IV. Jakarta, hlm. 80-81

${ }^{12}$ Nurma Sari, Pengarub Kepemilikan Manajerial, Kepemilikan Institusional, Kebijakan Dividen, Pertumbuban Perusabaan, Dan Profitabilitas Terbadap Kebijakan Hutang Perusabaan (Studi Empiris pada Perusahaan Manufaktur yang Terdaftar di Bursa Efek Indonesia). Universitas Negeri Yogyakarta, 2014, hlm. 29 ${ }^{13}$ Husein Syahatah. 2001. Pokok-pokok Pikiran Akuntansi Islam. Jakarta: Akbar Media Eka Sarana. Cet. I. hlm. 19

${ }^{14}$ Wartoyo S. 2013. Akuntansi Syari'ah : Sebuah Tinjauan Historis, hlm. 9
} 
pada tahun 610 Masihi iaitu al-Baqarah ayat 282. ${ }^{15}$ Walaupun kebanyakan orang sudah biasa dengan perakaunan pada tahun 1494 Masihi setelah penerbitan buku Luca Paciolli. Mengapa terjadi hal demikian? banyaknya anggapan yang menyatakan bahwa seolah perkembangan ilmu pengetahuan sekarang ini berasal dari penemuan Barat. Di dalamnya terdapat beberapa kemajuan peradaban yang tersembunyi atau dipijak seperti tamadun Islam (600-1250 M), budaya Rom, Yunani, Cina, India dan Parsi. Dalam buku yang ditulisnya dikenal sebagai asas pengiraan perakaunan moden. Sebenarnya, hampir semua aktiviti perakaunan rutin kita seperti penggunaan jurnal, lejar dan memorandum. Penjelasan lejar telah merangkumi aset, hutang, modal, pendapatan dan perbelanjaan. Dia juga menjelaskan entri penutup, dan menggunakan baki percubaan untuk mengetahui lejar. Penjelasan ini memberikan asas untuk perakaunan kos dan juga etika dalam perakaunan. ${ }^{16}$ Salah satu faktor pendorong lahirnya teori modern akuntansi syariah adalah butuhnya sistem akuntansi dalam lembaga bisnis syariah seperti Bank, Asuransi, pasar modal, trading, dan lain-lain, serta butuhnya pencatatan, pertanggungjawaban, dan pengawasan harta umat misalnya dalam Baitul Maal atau kekayaan milik umat Islam atau organisasinya. ${ }^{17}$

\section{Konsep Akuntansi Syariah}

Perakaunan dalam bahasa Arab adalah Al-Muhasabah yang berasal dari kata masdar hassaba-yuhasbu yang bermaksud menghitung atau mengukur. Dari segi, alMuhasabah mempunyai pelbagai asal kata ahsaba yang bermaksud "menjaga" atau "berusaha mendapatkan" juga berasal dari kata Ihtiasaba yang bermaksud "mengharapkan pahala di akhirat dengan menerima buku seseorang dari Tuhan", juga bermaksud "untuk menarik perhatian" atau " pertanggungjawabkannya". ${ }^{18}$ Sekiranya kata muhasabah dikaitkan dengan ihtisab dan gambarnya berkaitan dengan rakaman, maka maknanya adalah tindakan orang itu secara berterusan hingga ke pengadilan

${ }^{15}$ Departemen Agama RI. 2015. Al-Qur'an dan Terjemabanya, hlm. 70 ${ }^{16}$ Wartoyo S. 2013. Akuntansi Syari'ah : Sebuah Tinjauan Historis, hlm. 9 ${ }^{17}$ Sofyan Syafri Harahap. 2004. Akuntansi Islam. Jakarta : Bumi Aksara Cet.ke-4, hlm. 10)

${ }^{18}$ A.W. Munawwir. 2007. Kamus Al-Munawmir Indonesia Dan Arab. Surabaya : Pustaka Progressif; Mahmud Yunus, 2003. Kamus Arab Indonesia. Jakarta: Hindakarya Agung, hlm. 23 
akhirat dan melalui timbangan (mizan) sebagai alat pengukur, dan Tuhan sebagai akauntan. $^{19}$

Secara sederhana perakaunan syari'ah dapat dijelaskan melalui kata-kata akarnya, iaitu perakaunan dan syari'ah. Definisi umum perakaunan adalah pengenalpastian transaksi yang kemudian diikuti dengan merekod, mengklasifikasikan, dan meringkaskan urus niaga, sehingga menghasilkan penyata kewangan yang dapat digunakan untuk membuat keputusan. Sedangkan syari'ah adalah peraturan yang telah ditetapkan oleh Allah untuk dipatuhi oleh manusia dalam menjalankan semua aktiviti kehidupan mereka di dunia. Jadi perakaunan syari'ah adalah proses perakaunan untuk transaksi yang sesuai dengan peraturan yang ditetapkan oleh Allah. ${ }^{20}$ Menurut Sofyan Syafri, bahwa akuntansi memberikan informasi kuantitatif (Angka), ia memberikan informasi yang berfungsi dalam proses pengambilan keputusan (Keputusan), ia hanya mencatat yang berdampak moneter dan dinilai (Nilai) dengan nilai uang (Uang), ia hanya melakukan mencatatan transaksi (Transaksi) yang terjadi di perusahaan ataupun di instansi keuangan, akuntansi juga menjadi bahan untuk menganalisis (Analisa), ia netral (Netral) tidak memihak, ia seni karena memerlukan berbagai pertimbangan dan keahlian khusus bersifat subjektif (Seni), dan ia juga merupakan sistem informasi (Informasi). ${ }^{21}$

Menurut teorinya, perakaunan Islam adalah sekumpulan prinsip hipotesis, konsep dan pragmatik yang saling berkaitan antara satu sama lain yang membentuk kerangka rujukan untuk bidang pengetahuan. Sekiranya demikian, maka teori perakaunan dapat ditafsirkan sebagai penaakulan logik dalam bentuk seperangkat prinsip atau prinsip yang: (1) menjadi kerangka rujukan umum untuk menilai amalan perakaunan, dan (2) berfungsi sebagai panduan untuk pengembangan amalan dan pengeluar baru. Teori perakaunan boleh digunakan untuk menjelaskan amalan semasa, tetapi tujuan utama teori perakaunan adalah untuk membuat kerangka rujukan untuk menilai dan mengembangkan amalan perakaunan yang baik. ${ }^{22}$

${ }^{19}$ Ali Mauludi AC. 2014. Akuntansi Syariah; Pendekatan Normatif, Historis dan Aplikatif. Iqtishadia Vol . 1 No. 1 Juni, hlm. 60

${ }^{20}$ Nurma Sari, Pengarub Kepemilikean Manajerial, hlm. 34

${ }^{21}$ Sofyan Syafri Harahap. 2004. Akuntansi Islam, hlm. 27-28; Nurma Sari, 2014: 34).

${ }^{22}$ Nurma Sari, Pengarub Kepemilikan Manajerial, hlm. 3 
Konsep asas (ciri asas), juga disebut andaian atau postulat, adalah aksioma atau pernyataan yang tidak perlu dibuktikan lagi kerana secara amnya ia telah diterima agar sesuai dengan objektif penyata kewangan, dan menggambarkan persekitaran ekonomi, politik, sosial, dan perundangan di mana perakaunan beroperasi . Ia berasal dari tujuan penyata kewangan, berfungsi sebagai landasan prinsip perakaunan. Tujuan penyata kewangan perakaunan syariah adalah untuk memberikan akauntabiliti dan maklumat. Konsep asas perakaunan adalah entiti perakaunan, kesinambungan, unit pengukuran, dan tempoh perakaunan. ${ }^{23}$

Konsep asas perakaunan syariah adalah Entiti Perniagaan (al Wihdah alIqtishadiyah), iaitu prinsip kebebasan jaminan kewangan. Serta wujudnya Keberlanjutan (keprihatinan berterusan), yang mencuba dunia anda seolah-olah anda akan hidup selamanya dan berusaha untuk akhirat anda seolah-olah anda akan mati esok (Ali bin Abi Talib). Juga adanya Stabilitas Daya Beli Unit Moneter (The Stability of the Purchasing Power of the Monetary Unit), yaitu unit pengukur (unit of measure) atau unit moneter (monetary unit). Pada zaman Rasulullah saw, satu dirham (uang perak) senilai seekor ayam, satu dinar adalah nilai tukar seekor kambing dewasa, harga ini berlaku sampai sekarang. ${ }^{24}$ Serta perlunya Periode, yaitu hubungan antara akuntansi dengan yang lainya, misalnya hubungan antara kewajiban membayar zakat dengan dasar periode akuntansi (haul) (Nurma Sari, 2014: 38; Sigit Purnawan, 2001: 126). Sedangkan fungsi Akuntansi adalah Memberi informasi kuantitatif, yang bersifat financial, mengenai suatu usaha / business dan sebagai dasar pengambila keputusan (Ali Mauludi, 2014: 61).

\section{PEMBAHASAN}

\section{Ayat-Ayat Akuntansi}

Al-Qur'an adalah kitab suci umat Islam yang sangat universal, yaitu mencakup segala aspek kehidupan manusia dunia dan akhirat. Kitab yang

\footnotetext{
${ }^{23}$ Rosjidi. 1999. Teori Akuntansi: tinjauan, konsep, dan struktur. Jakarta: Lembaga Penerbitan FE-UI, hlm. 21

${ }^{24}$ Sigit Purnawan Jati. 2001. Seputar Dinar dan Dirham, Dalam Muhammad Ismail Yusanto dkk (ed.), Dinar Emas, solusi Krisis Moneter. cet.1 (Jakarta:PIRAC, SEM Institute, Infid, hlm. 37
} 
melambangkan keterkaitan manusia dengan pencipta dan manusia dengan sesamanya (habum minallah dan hablum minannasa). Berkaitan dengan hablum minananaas yang sangat urgen adalah dalam bidang muamalah ekonomi dan transaksi. Dalam bertransaksi secara legal dan berkeadilan perlu adanya transaparansi dengan di buktikan melalui catatan sirkulasi keuangan atau disebut dengan akuntansi. Dalam alQur'an banyak sekali memuat ayat-ayat tentang muamalah ekonomi, diantaranya ayatayat tentang akuntansi. Maka dalam hal ini penulis akan memamparkan ayat-ayat akuntansi dalam al-Qur'an secara umum. Dalam tulisan ini, penulis akan mengurutkan sesuai urutan surah dalam al-Qur'an yang dimulai dengan surah alFatihah (1) dan berakhir pada surah an-Nas (114). Adapaun ayat-ayat akuntansi dalam al-Qur'an terdapat dalam 18 surah dan 25 ayat, maka surah dan ayat tersebut adalah sebagai berikut:

1) Surah al-Baqarah (2) ayat 202:

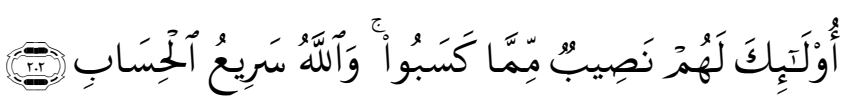

Artinya: Mereka adalah orang yang mendapat lebih banyak daripada yang mereka cuba dapatkan; dan Allab sangat cepat dalam perbitungan-Nya. ${ }^{25}$

Surah al-Baqarah (2) ayat 212:
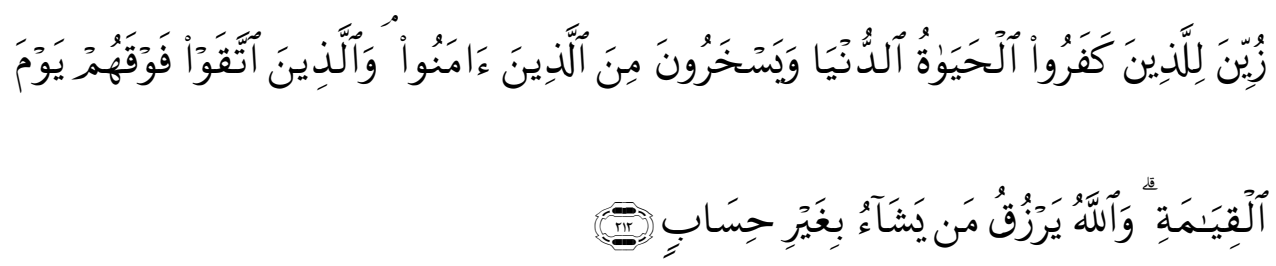

Artinya: Kebidupan dunia menjadi indah di mata orang-orang yang tidak percaya, dan mereka memandang rendah orang-orang yang beriman. sedangkan orang-orang yang soleh lebih mulia daripada pada hari kiamat. dan Allah memberi rezeki kepada mereka yang Dia kehendaki tanpa had. ${ }^{26}$

2) Surah al-Imran (3) ayat 19:

25Departemen Agama RI. 2015. Al-Qur'an dan Terjemabanya, hlm. 49

${ }^{26}$ Ibid., hlm. 51 


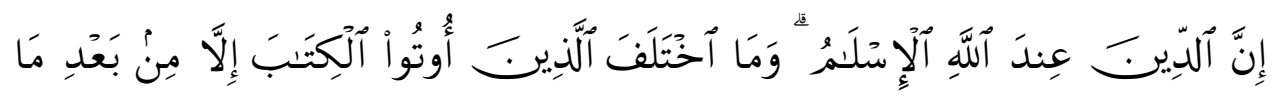

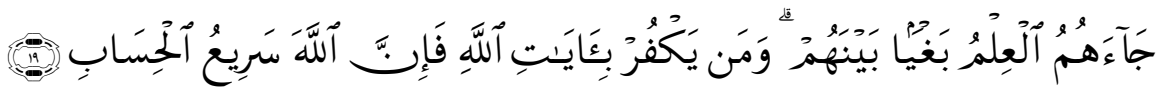

Artinya: Sebenarnya agama (diberkati) oleh Allah hanya Islam. tidak ada perselisiban di antara mereka yang telah diberi Kitab (yang bermaksud bahawa kitab-kitab itu diturunkan sebelum Al-Quran) kecuali setelah pengetabuan datang kepada mereka, Kerana niat jahat (yang ada) di antara mereka. barangsiapa yang tidak mempercayai ayat-ayat Allah, sesunggubnya Allah memperbitungkannya dengan cepat. ${ }^{27}$

Surah al-Imran (3) ayat 27:

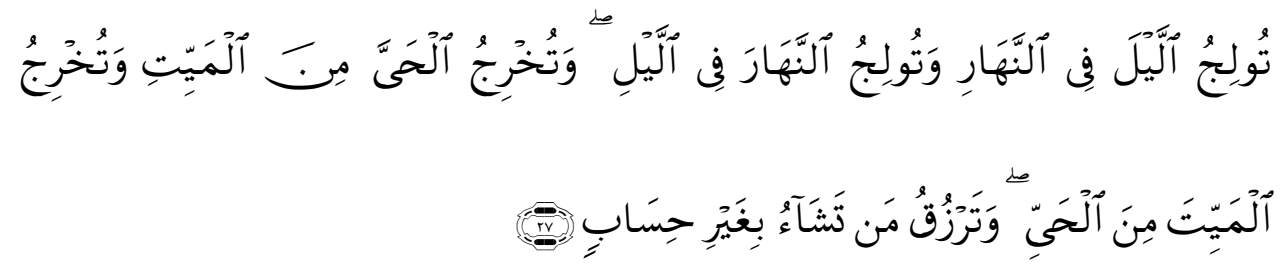

Artinya: Anda meletakkan malam ke dalam siang dan Anda meletakekan siang ke malam. Anda mengeluarkan yang bidup dari yang mati, dan anda mengeluarkan yang mati dari yang bidup beberapa Mufassirin memberikan contoh untuk ayat ini dengan mengeluarkan anak ayam dari telur dan telur dari ayam) dan juga dapat ditafsirkan bahawa putaran kuasa antara bangsa dan tenggelamnya sesuatu yang manusia menurut undang-undang Tuban). dan anda memberi kekayaan kepada siapa yang anda mahukan tampa memperbitungkan (bad) ". ${ }^{28}$

Surah al-Imran (3) ayat 37:

${ }^{27}$ Ibid., hlm. 78

${ }^{28} \mathrm{Ibid}$., hlm. 79 


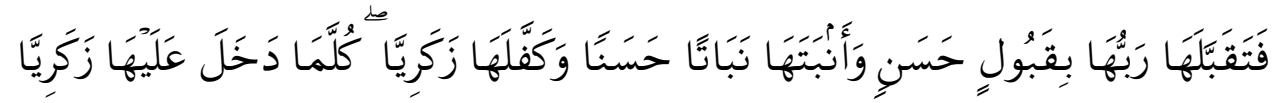

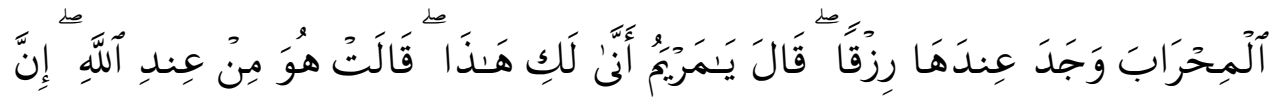

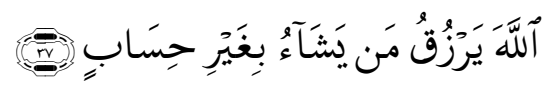

Artinya: Maka Tubannya menerimanya (sebagai sumpab) dengan penerimaan yang baik, dan mendidiknya dengan pendidikan yang baik dan Tuban menjadikan Zakariya penjaganya. setiap kali Zakariya masuk menemui Mary di mibrab, dia menjumpai makanan di sisinya. Zakariya berkata: "Wahai Maria, dari mana kamu mendapat (makanan) ini?" Maryam menjawab: "Makanan dari sisi Allah". Sesunggubnya, Allab memberi rezekei kepada sesiapa yang Dia kehendaki tanpa perbitungan. ${ }^{29}$

3) Surah al-Maidah (5) ayat 4:

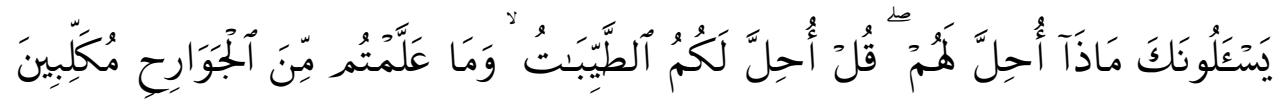

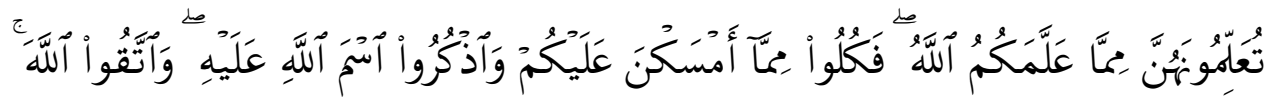

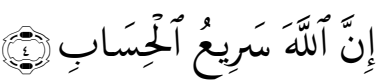

Artinya: Mereka bertanya kepada anda, "Apa yang diperbolebkan bagi mereka?" Katakanlah: "Dibolehkan bagi anda untuk bersikap baik dan (diburu) oleh binatang liar yang telah anda ajarkan dengan melatihnya untuk memburu; anda mengajarnya sesuai dengan apa yang telah diajarkan oleh Tuban kepada anda. pemikiran dan inspirasi manusia dari Tuban tentang melatih binatang liar dan cara memburu. Oleh itu, makanlah dari apa yang mereka tangkap untuk anda (iaitu: binatang liar yang diburu yang ditangkap semata-mata untuk anda dan tidak dimakan sama sekali oleh baiwan itu), dan sebutlah nama Tuban atas

${ }^{29}$ Ibid., hlm. 81 
binatang binatang buas (ketika melepaskannya) (maksudnya: ketika melepaskan binatang itu disebut nama Tuban dan bukannya binatang yang diburu itu sendiri menyebutkan waktu untuk menerkam permainan), dan takut kepada Allah, sesunggubnya Allah sangat memperbitungkan Hisab. ${ }^{30}$

4) Surah al-An'am (6) ayat 52:
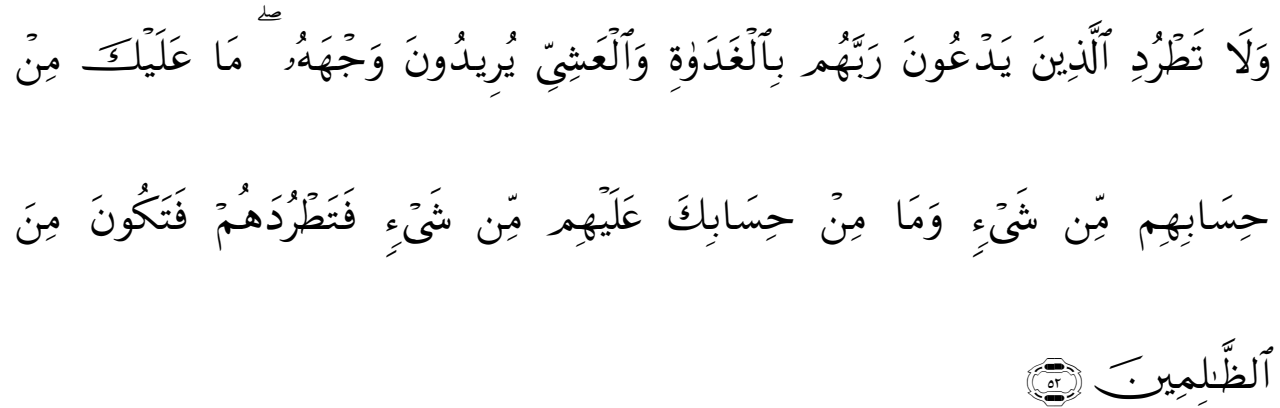

Artinya: Dan jangan menghalau orang-orang yang menyeru Tuban mereka pada waktu pagi dan petang, sedangkan mereka menginginkan keredhaan-Nya. anda tidak memikul sedikit pun tanggung jawab atas tindakan mereka dan mereka juga tidak memikul sedikit pun tanggung jawab atas tindakan anda, yang menyebabkan anda (berbak) mengusir mereka, (sehingga anda termasuk di antara mereka yang melakukan kesalahan) (ketika Rasulullab sedang duduk. bersama-sama dengan orang-orang yang beriman yang Dianggap rendab dan miskin oleh orang Quraisy, sejumlah pemimpin Quraisy datang untuk berbicara dengan Rasulullah, tetapi mereka enggan duduk bersama orang-orang yang beriman, dan mereka menyarankan agar orang-orang beriman dibalau, maka ayat ini turun). ${ }^{31}$

5) Surah Yunus (10) ayat 5:

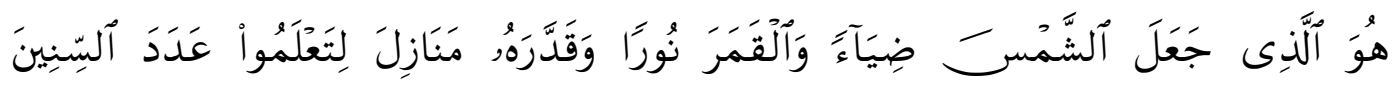

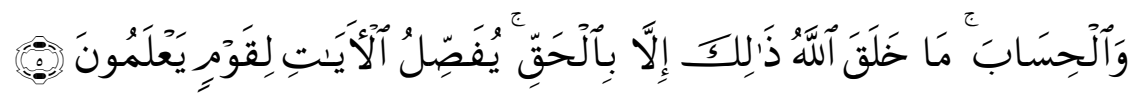

30Ibid., hlm. 158

${ }^{31}$ Ibid., hlm. 194 
Artinya: Dialab yang menjadikan matahari bersinar dan bulan bersinar dan Dia menetapkan Manzilab (tempat) untuk perjalanan bulan, sehingga anda mengetahui jumlah tabun dan perbitungan (waktu). Tuhan tidak menciptakan perkara-perkara itu melainkan dengan bak-hak (maksudnya: Tuban menjadikan semua perkara yang disebutkan tidak berguna, tetapi dengan kebijaksanaan). dia menjelaskan tanda-tanda (kebesaran-Nya) kepada mereka yang tahu. ${ }^{32}$

6) Surah al-Ra'du (13) ayat 18:
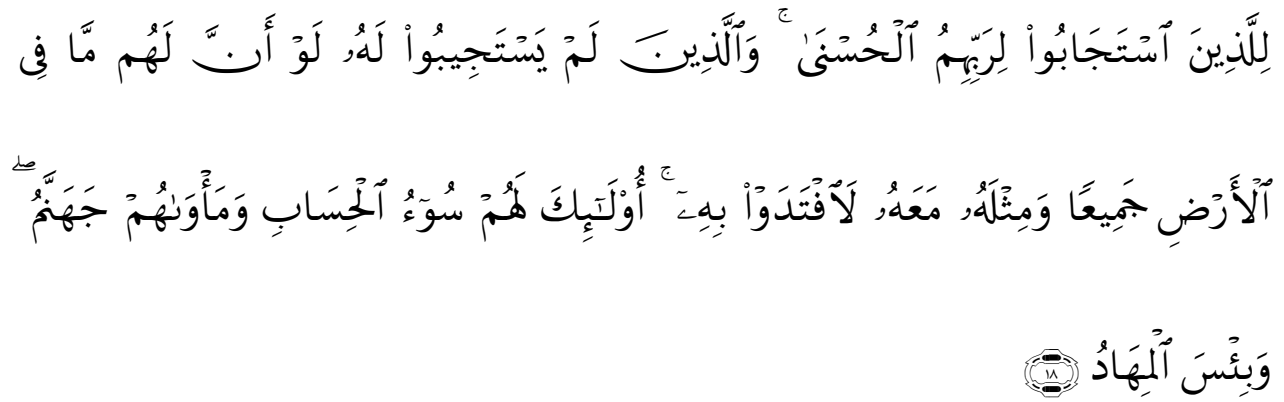

Artinya: Bagi mereka yang memenubi panggilan Tuban mereka, (dengan syarat) pembalasan yang baik. dan orang-orang yang tidak memenubi panggilan Tuban, jika mereka memiliki semua (kekayaan) yang ada di bumi dan (ditambah) sebanyak isi bumi lagi dengannya, pasti mereka akan menebus diri mereka dengan kekayaan itu. orang-orang memberinya perbitungan yang buruk dan tempat tinggal mereka adalah Neraka dan itulah tempat paling buruk untuk tinggal. ${ }^{33}$

Surah al-Ra'du (13) ayat 21:

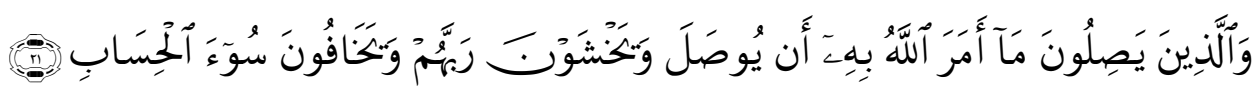

Artinya: Dan orang-orang yang menghubungkan apa sabaja yang diperintabkan oleb

Allab untuk dibubungkan (iaitu untuk menjalin persahabatan dan bubungan kekeluargaan), dan mereka takut kepada Tuhan dan takut akan perbitungan yang buruk. ${ }^{34}$

\footnotetext{
${ }^{32} \mathrm{Ibid} .$, hlm. 306

${ }^{33}$ Ibid., hlm. 371

${ }^{34}$ Ibid., hlm. 372
} 
Surah al-Ra'du (13) ayat 40:

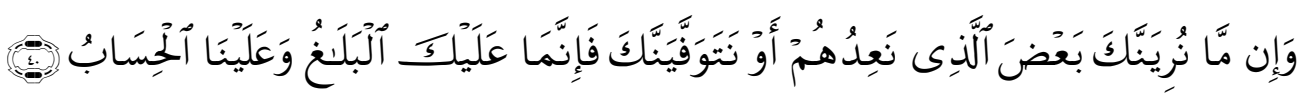

Artinya: Dan jika kami menunjuk.kan kepada anda bahagian (penyiksaan) yang kami mengancam mereka atau kami akan mengingat anda (tidak, penting bagi anda) Kerana tugas anda hanyalah menyampaikannya, sedangkan Kami adalah orang yang menilai perbuatan mereka. ${ }^{35}$

Surah al-Ra'du (13) ayat 41:

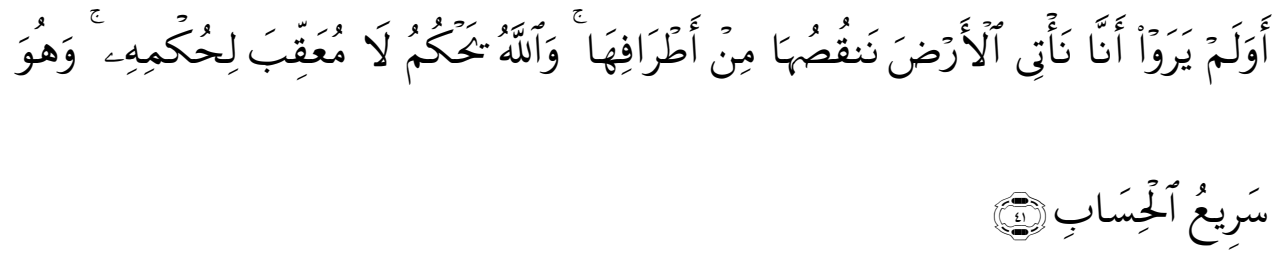

Artinya: Dan apakah mereka tidak melihat bahawa sesunggubnya kita datang ke daerab-daerah (orang-orang kafir), lalu kita mengurangkan kawasan-kawasan ini (sedikit demi sedikit) dari tepi? dan Allab menetapkan undang-undang (menurut kehendak-Nya), tidak ada yang dapat menolak perintabNya; dan Dialah yang cepat memperbitungkan. ${ }^{36}$

7) Surah Ibrahim (14) ayat 41:

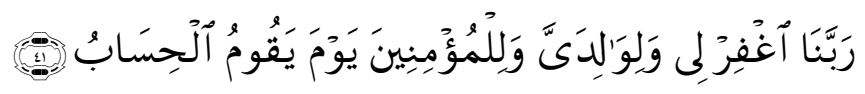

Artinya: Ya Tuban kami, ampunilab aku dan kedua ibu ayabku dan semua orangyang beriman pada hari perbitungan (hari kiamat) ". ${ }^{37}$

8) Surah al-Isra (17) ayat 12:

${ }^{35}$ Ibid., hlm. 376

36Ibid., hlm. 376

${ }^{37}$ Ibid., hlm. 386 


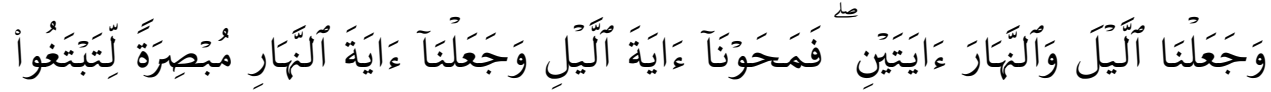

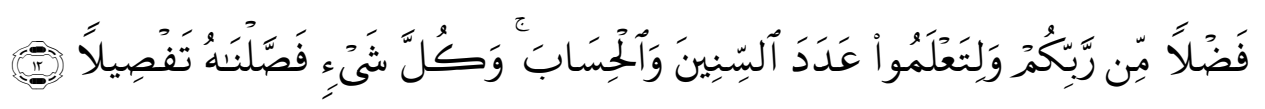

Artinya: Dan kami membuat malam dan siang dua tanda, kemudian kami menghapus tanda-tanda malam dan kami menjadikan tanda-tanda siang itu terang, sehingga kamu mencari berkat Tuhanmu, dan agar kamu mengetabui jumlah tabun dan perbitungannya. dan semua yang telah kami jelaskan dengan jelas. ${ }^{38}$

9) Surah al-Anbiya (21) ayat 1 :

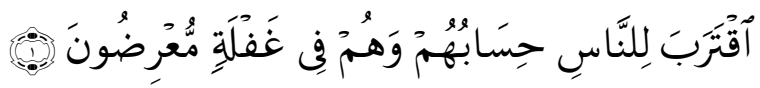

Artinya: Sudah dekat dengan orang-orang hari ini untuk memperbitungkan semua amalan mereka, sementara mereka lalai lagi berpaling (dari itu). ${ }^{39}$

10) Surah al-Mukminun (23) ayat 117:

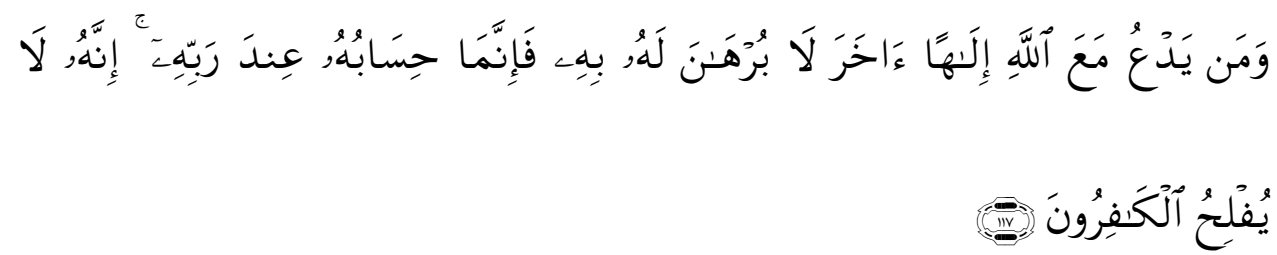

Artinya: Dan barangsiapa menyembah Tuban yang lain selain Allah, walaupun tidak ada bukti kepadanya tentang hal itu, maka perbitungan itu ada di sisi Tuban. Sesunggubnya, mereka yang tidak percaya tidak bernasib baik. ${ }^{40}$

11) Surah al-Nur (24) ayat 38:

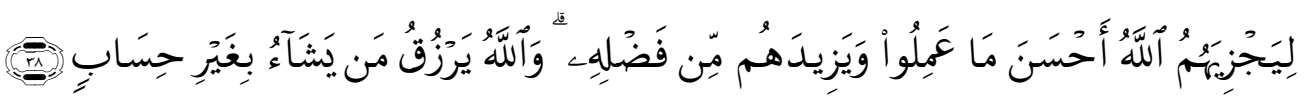

Artinya: (Mereka melakukan ini) supaya Tuban memberi ganjaran kepada mereka (sebagai balasannya) yang lebih baik daripada apa yang telah mereka lakukan,

\footnotetext{
${ }^{38}$ Ibid., hlm. 426

${ }^{39} \mathrm{Ibid} ., \mathrm{hlm} .495$

${ }^{40}$ Ibid., hlm. 540
} 
dan agar Tuban menambabkan pemberian-Nya kepada mereka. dan Allah memberi rezeki kepada sesiapa yang Dia kehendaki tanpa had. ${ }^{41}$

12) Surah Shaad (38) ayat 39:

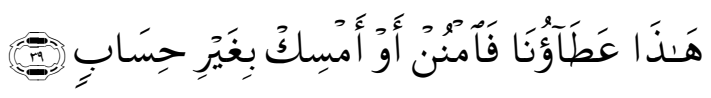

Artinya: Ini adalah hadiah kami; Kemudian berikan (kepada orang lain) atau pegang (untuk diri sendiri) tanpa tanggungjawab. ${ }^{42}$

13) Surah al-Zumar (39) ayat 10:

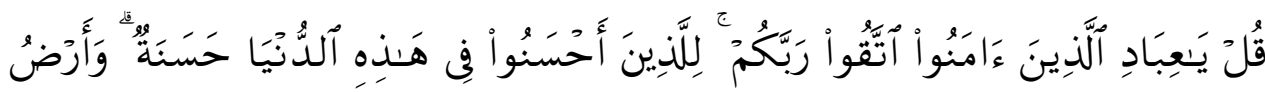

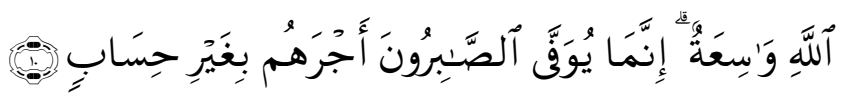

Artinya: Katakanlah: "Hai hamba-hamba-Ku yang setia, bertakwalah kepada

Tubanmu". mereka yang berbuat baik di dunia ini menjadi baik. dan bumi

Tuban luas. Pasti hanya mereka yang sabar akan diberi ganjaran tanpa had. ${ }^{43}$

14) Surah al-Thalaq (65) ayat 8 :

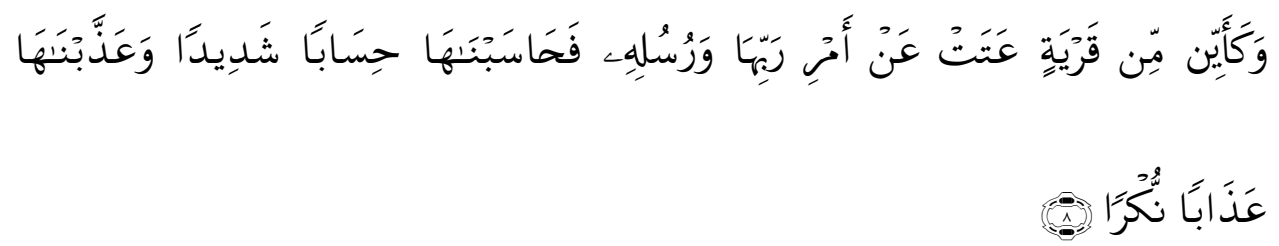

Artinya: Dan berapa banyak. (penduduk) negeri itu yang tidak mematubi perintah Tuban dan rasul-rasul mereka, Oleh itu, kami memperbitungkan penduduk di negeri itu dengan perbitungan yang keras, dan kami menakdirkan mereka dengan azab yang mengerikan (apa yang dimaksud dengan perbitungan dan azab di sini adalah perhitungan dan azab di akbirat). ${ }^{44}$

${ }^{41}$ Ibid., hlm. 550

${ }^{42} \mathrm{Ibid} ., \mathrm{hlm} .737$

${ }^{43} \mathrm{Ibid} .$, hlm. 747

${ }^{44}$ Ibid., hlm. 947 
15) Surah al-Haqah (69) ayat 20:

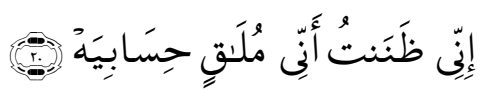

Artinya: Sesunggubnya, saya yakin bahawa sesunggubnya saya akan menemui myab terbadap saya. ${ }^{45}$

Surah al-Haqah (69) ayat 52:

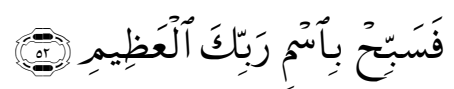

Artinya: Oleb itu, muliakanlah (nama) nama Tuhanmu yang agung. ${ }^{46}$

16) Surah al-Naba' (78) ayat 27 :

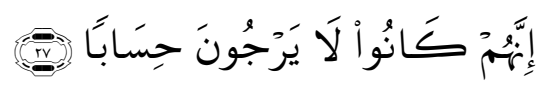

Artinya: Sesunggubnya mereka tidak mengharapkan (takut) perbitungan. ${ }^{47}$

17) Surah al-Insyiqaq (84) ayat 3:

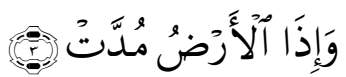

Artinya: Dan apabila bumi diratakan. ${ }^{48}$

18) Surah al-Ghasyiayah (88) ayat 26:

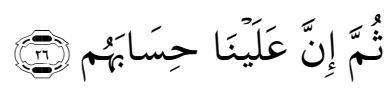

Artinya: Maka tentunya kewajiban kita adalah memperbitungkannya. ${ }^{49}$

${ }^{45}$ Ibid., hlm. 969

${ }^{46}$ Ibid., hlm. 971

${ }^{47}$ Ibid., hlm. 1016

${ }^{48}$ Ibid., hlm. 1040

${ }^{49}$ Ibid., hlm. 1055 


\section{Rekontruksi Ayat-ayat Akuntansi Syariah}

Rekontruksi akuntansi syariah dengan ayat-ayat akuntansi dalam bingkai prinsip dasar akuntansi adalah sebagai berikut:

1. Dilaporkan secara benar, hal ini terdapat dalam al-Qur'an surah:

1) Surah Yunus (10) ayat 5.

2. Cepat laporannya, hal ini terdapat dalam al-Qur'an surah:

1) Surah al-Baqarah (2) ayat 202.

2) Surah al-Imran (3) ayat 19.

3) Surah al-Maidah (5) ayat 4.

4) Surah al-Ra'du (13) ayat 41.

3. Dibuat oleh ahlinya (akuntan), hal ini terdapat dalam al-Qur'an surah:

1) Surah al-Ra'du (13) ayat 21.

2) Surah al-Ra'du (13) ayat 40.

3) Surah al-Mukminun (23) ayat 117.

4) Surah al-Ghasyiayah (88) ayat 26.

4. Terang, jelas, tegas dan informatif, hal ini terdapat dalam al-Qur'an surah:

1) Surah al-Isra (17) ayat 12.

2) Surah Ibrahim (14) ayat 41.

3) Surah al-Insyiqaq (84) ayat 3.

5. Memuat informasi yang menyeluruh, hal ini terdapat dalam al-Qur'an surah:

1) Surah al-An'am (6) ayat 52.

2) Surah al-Zumar (39) ayat 10.

6. Informasi ditujukan kepada semua pihak yang terlibat secara horizontal maupun vertikal, hal ini terdapat dalam al-Qur'an surah:

1) Surah al-Baqarah (2) ayat 212.

2) Surah al-Imran (3) ayat 27.

3) Surah al-Imran (3) ayat 37.

4) Surah al-Ra'du (13) ayat 18.

5) Surah al-Ra'du (13) ayat 40.

6) Surah al-Nur (24) ayat 38.

7) Surah Shaad (38) ayat 39. 
8) Surah al-Haqah (69) ayat 52.

7. Terperinci dan teliti, hal ini terdapat dalam al-Qur'an surah:

Surah al-Thalaq (65) ayat 8

8. Tidak teradi manipulasi, hal ini terdapat dalam al-Qur'an surah:

1) Surah al-Haqah (69) ayat 20.

2) Surah al-Naba' (78) ayat 27.

9. Dilakukan secara kontinu (tidak lalai), hal ini terdapat dalam al-Qur'an surah:

1) Surah al-Anbiya (21) ayat 1.

Namun, rekontruksi ayat-ayat al-Qur'an secara umum yang menjadi prinsip akuntansi syariah adalah sebagaimana di uraikan dalam surat al-Baqarah, ayat 282 adalah sebagai berikut:

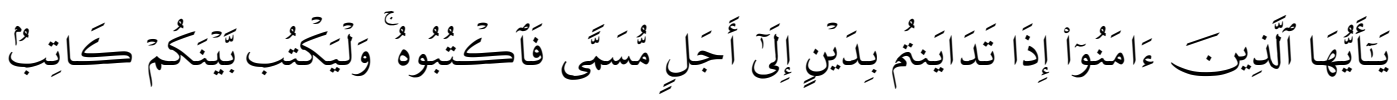

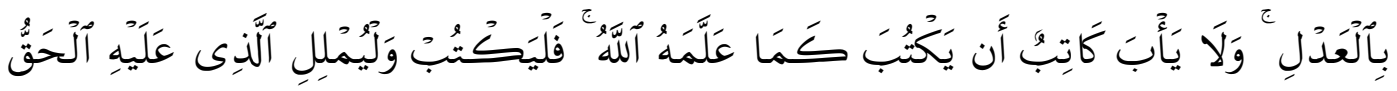

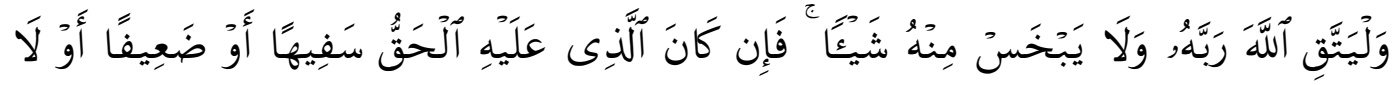

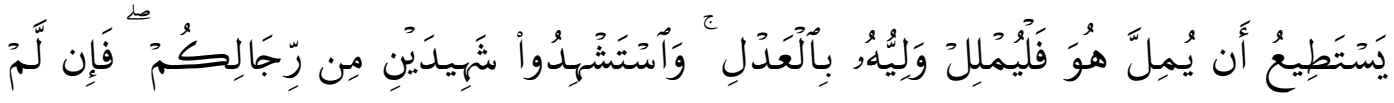

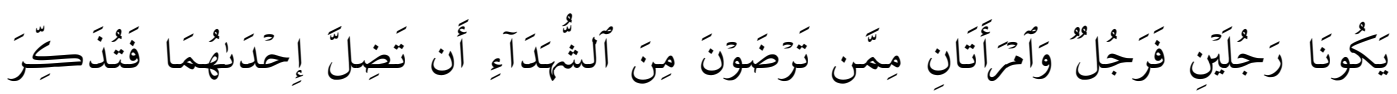

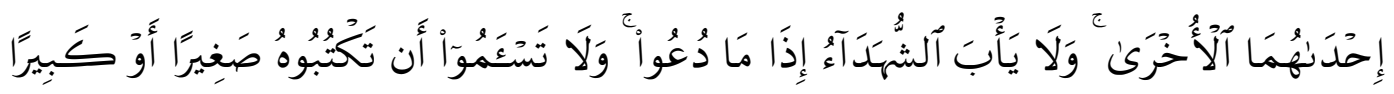

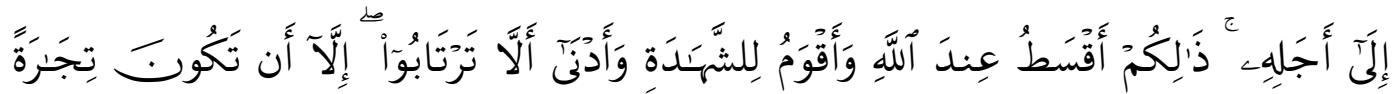

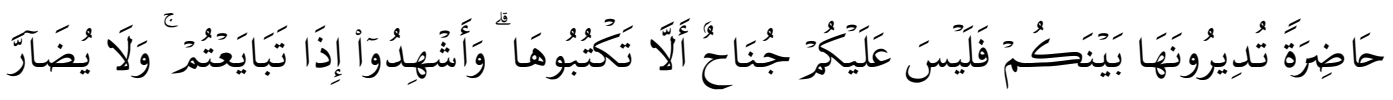




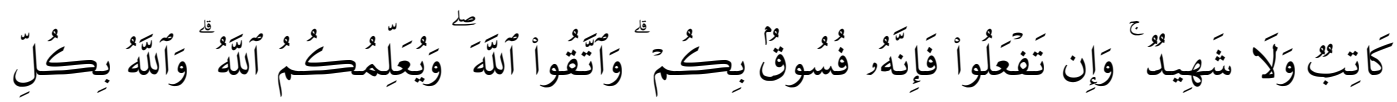

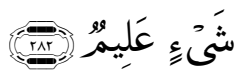

Artinya: Wabai orang-orang yang percaya, jika anda bermu'amalah (bermuamalab seperti menjual, membayar butang, atau menyewakan dan sebagainya) tidak secara tunai untuk waktu yang ditentukan, anda harus menuliskannya. dan biarkan seorang penulis di antara anda menulisnya dengan betul. dan janganlah penulis enggan menulisnya sebagaimana yang diajarkan oleh Tuban, mereka harus menulisnya, dan membiarkan orang yang berbutang itu mengajarkannya (apa yang akan ditulisnya), dan biarkan dia takut kepada Allah, Tubannya, dan janganlah dia mengurangkan sedikit pun butangnya. jika penghutang adalah orang yang fikirannya lemah atau lemah (keadaannya) atau dia sendiri tidak dapat memimpin, maka hendaklah penjaganya mengajarnya dengan jujur. dan saksikan dengan dua saksi lelaki itu (di antara kamu). jika tidak ada dua lelaki, maka (mungkin) seorang lelaki dan dua wanita dari saksi yang anda sukai, sehingga jika seseorang lupa, maka satu orang mengingatkannya. jangan menjadi saksi yang enggan (memberi maklumat) semasa mereka dipanggil; dan jangan jemu menulis hutang itu, sama ada kecil atau besar sebingga tarikh akhir pembayarannya. iaitu, lebih adil kepada Allah dan menguatkan kesaksian dan lebih dekat untuk tidak (menimbulkan) keraguan anda. (Tulis mu'amalah anda), kecuali jika mu'amalah adalah perdagangan tunai yang anda jalankan di antara anda, maka tidak ada dosa bagi anda, (jika) anda tidak menulisnya. dan saksikan sekiranya anda menjual dan membeli; dan jangan biarkan penulis dan saksi menyusabkan satu sama lain. jikea anda melakukannya (itu), maka itu pasti adalah kejahatan dalam diri anda. dan bertakwalah kepada Allab; Tuban mengajar anda; dan Allah mengetabui segalanya. ${ }^{50}$

Kemudian penyusunan semula prinsip perakaunan syariah secara sistematik melihat maklumat di bawah:

1. Prinsip Liabiliti. Implikasinya dalam perniagaan dan perakaunan adalah bahawa individu yang terlibat dalam amalan perniagaan mesti selalu

${ }^{50}$ Ibid., hlm. 70 
bertanggungjawab terhadap apa yang telah diberi mandat dan dilakukan kepada pihak-pihak yang berkenaan dan biasanya dalam bentuk laporan perakaunan.

2. Prinsip Keadilan. Kata keadilan dalam konteks aplikasi perakaunan mengandungi dua makna, iaitu:

1) Berkaitan dengan amalan moral, yang merupakan faktor yang sangat dominan.

2) Perkataan itu lebih mendasar (dan masih bertumpu pada nilai etika / syariah dan moral).

3. Prinsip Kebenaran. Prinsip kebenaran ini tidak dapat dipisahkan dari prinsip keadilan. Kebenaran dalam Al-Quran tidak boleh dikelirukan dengan kejahatan. Al-Quran telah menggariskan, bahawa ukuran, alat atau alat untuk menentukan kebenaran tidak berdasarkan nafsu.

Ayat rekontruksi akuntansi syariah yang lainnya dengan secara eksplisit menerangkan konsep akuntansi dalam al-Quran adalah4:

1. Surah al-Syu'ara (26) ayat 181-184, mengenai penyempurnaan takaran dan timbangan dengan baik; perintah jangan merugikan manusia pada hak-haknya dan bertakwa kepada Allah swt. Ayatnya sebagai berikut:

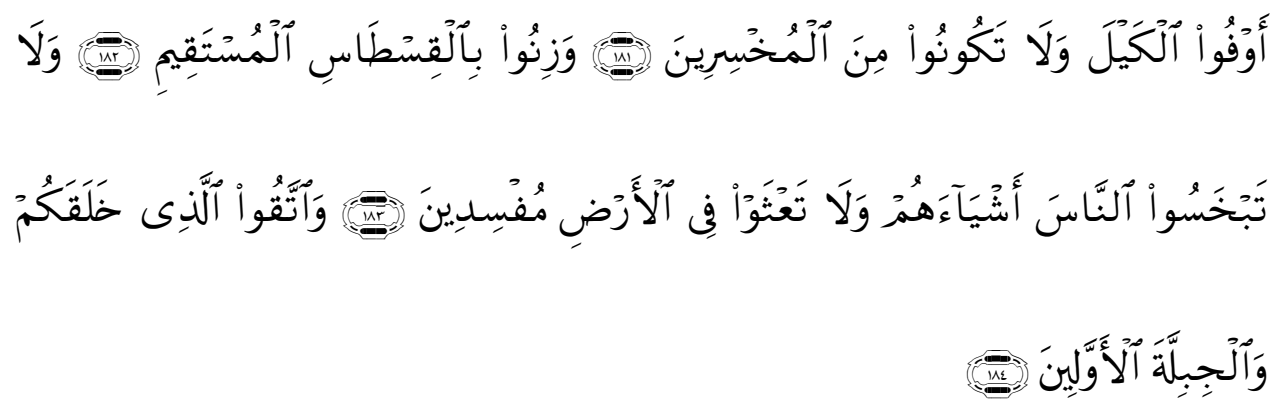

Artinya: Lengkapkan ukuran dan jangan memasukekan mereka yang memudaratkan.

Dan timbang dengan skala lurus. Dan jangan menyakiti manusia atas baknya, dan jangan berleluasa di bumi dengan membuat kerosakan. Dan bertakwalah kepada Allah, yang menciptakan kamu dan orang-orang yang $1 "{ }^{51}$

${ }^{51}$ Ibid., hlm. 586-587 
2. Surah al-Hujarat (49) ayat 6, yang menerangkan proses auditing (tabayyun) dengan teliti dan benar tanpa menimpakan suatu musibah atau bahaya kepad orang lain. Ayatnya sebagai berikut:

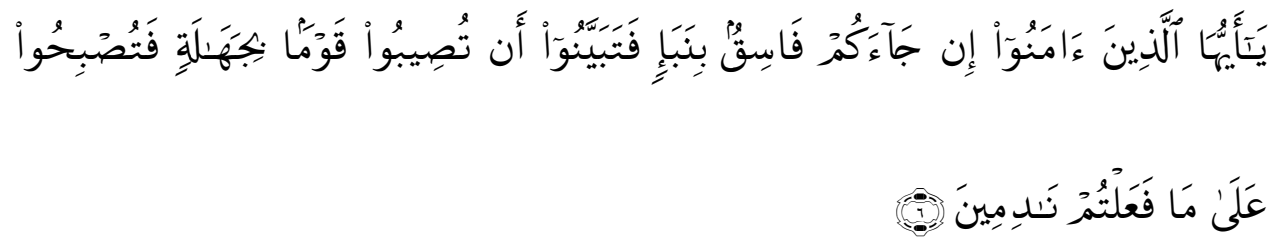

Artinya: Wahai orang-orang yang beriman, jika kamu datang kepada orang fasik membawa pesan, maka periksa dengan teliti agar kamu tidak menimpa musibah pada suatu bangsa tanpa mengetabui keadaan yang menyebabkan kamu menyesali tindakanmu. ${ }^{52}$

3. Surah al-Israa (17) ayat 35, yang menerangkan pengukuran dalam bentuk pospos yang dilakukan dalam neraca. Ayatnya sebagai berikut:

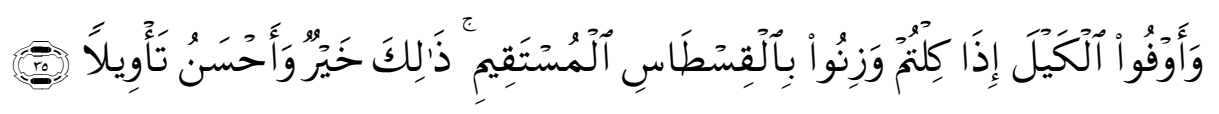

Artinya: Dan selesaikan ukuran jika anda mengukur, dan timbang dengan timbangan yang betul. Itu lebih penting (untuk anda) dan kesan yang lebib baik.. ${ }^{53}$

\section{KESIMPULAN}

Rekontruksi Ayat-ayat akuntansi syariah dengan induk ayatnya (Q.S (2): 282; (26): 181-184; (49): 6; (17): 35). Sedangkan prinsip pelaporan akuntansi syariah ada 9 macam, yaitu: Dilaporkan secara benar (Q.S (10): 5); Cepat laporannya (Q.S (2): 202; (3): 19; (5): 4; (13): 41); Dibuat oleh ahlinya (akuntan) (Q.S (13): 21; (13): 40; (23): 117; (88): 26); Terang, jelas, tegas dan informatif (Q.S (17): 12; (14): 41; (84): 3); Memuat informasi yang menyeluruh (Q.S 6: 52; 39:10); Informasi ditujukan kepada semua pihak yang terlibat secara horizontal maupun vertikal (Q.S (2): 212; (3): 27; (3): 37; (13): 18; (13): 40; (24): 38; (38): 39; (69): 52); Terperinci dan teliti (Q.S (65): 8);

${ }^{52}$ Ibid., hlm. 84

${ }^{53}$ Ibid., hlm. 429 
Tidak teradi manipulasi (Q.S (69): 20; (78): 27); Dilakukan secara kontinu (tidak lalai) (Q.S (21): 1).

\section{DAFTAR PUSTAKA}

A.W. Munawwir. 2007. Kamus Al-Munammir Indonesia Dan Arab. Surabaya : Pustaka Progressif.

Ali Mauludi AC. 2014. Akuntansi Syariab; Pendekatan Normatif, Historis dan Aplikatif. Iqtishadia Vol 1 No. 1 Juni.

Departemen Agama RI. 2015. Al-Qur'an dan Terjemahanya. Jakarta. Depag RI.

Elex Sarmigi. 2018. Analisis Komparasi Perilaku Etis Mahasiswa Akuntansi Stie Sakti Alam Kerinci Dengan STIE Sumatera Barat Dan Faktor-Faktor Yang Mempengarubinya (Jurnal Akuntansi \& Ekonomi FE. UN PGRI Kediri Vol. 3 No. 1, Maret)

Husein Syahatah. 2001. Pokok-pokok Pikiran Akuntansi Islam. Jakarta: Akbar Media Eka Sarana. Cet. I.

I Wayan Suartana. 2010). Akuntansi Keperilakuan; Teori dan Implementasi. Yogyakarta: Penerbit Andi.

M. Anas. 2018. Pembelajaran Akuntansi Berbasis Spiritualitas, Budaya Dan Kearifan Lokal (Jurnal Akuntansi \& Ekonomi FE. UN PGRI Kediri Vol. 3 No. 1, Maret)

Mahmud Yunus, 2003. Kamus Arab Indonesia. Jakarta: Hindakarya Agung.

Marhaendra Kusuma. 2017. Internalisasi Nilai Pancasila Dalam Mata Kuliah Akuntansi Biaya (Suatu Studi Pengukuran Efektivitas Learning Outcome). Jurnal Akuntansi \& Ekonomi FE. UN PGRI Kediri Vol. 2 No. 2, September.

Milam Ashuri. Akuntansi Syariah, lihat wibesite online di alamat https://milamashuri.wordpress.com/2015/04/05/akuntansisyariah/.diakses.tgl.12.september.2018.

Rosjidi. 1999. Teori Akuntansi: tinjauan, konsep, dan struktur. Jakarta: Lembaga Penerbitan FE-UI.

Sigit Purnawan Jati. 2001. Seputar Dinar dan Dirham, Dalam Muhammad Ismail Yusanto dkk (ed.), Dinar Emas, solusi Krisis Moneter. cet.1 (Jakarta:PIRAC, SEM Institute, Infid)

Sofyan Syafri Harahap. 2004. Akuntansi Islam. Jakarta : Bumi Aksara Cet.ke-4.

Sri Nurhayati \& Wasilah. 2011. Akuntansi Syari'ah di Indonesia. Jakarta: Salemba Empat

Sri Nurhayati. 2013. Akuntansi Syari'ah di Indonesia. Salemba IV. Jakarta.

Suwarjono. 2005. Teori Akuntansi Perekayasaaan Pelaporan Keuangan. Yogyakarta. BPFE.

Wartoyo S. 2013. Akuntansi Syari'ah : Sebuah Tinjanan Historis, Jurnal Adzkia Islamic and Finance Volume 1 No 1 
Wartoyo. 2018. Akuntansi Syari'ah : Sebuah Tinjauan Historis. Makalah Proseding PDF. https://www.academia.edu/26079680/Akuntansi_Syariah_Sebuah_Tinjauan _Historis.12.09.2018.

Wartoyo. T.th. Sejarah Pemikiran Akuntansi Syariah. IAIN Syekh Nurjati Cirebon Email : san_diero2000@yahoo.com. 